\title{
Have a Heart for the Holocene: The Politics of Ark Activism, Collaborative Conservation, and Sponsored Survival at Museums
}

\author{
Timothy W. Luke
}

Science should never fully rest upon settled consensus, even though intense conflicts at key conjunctures in many scientific research programs often trigger such demands. Proponents of the Anthropocene thesis in various disciplines and different countries are lobbying hard now to force a consensus about its actuality, believing that the dire changes associated with this new epoch will alarm inventors and industrialists enough to slow rapid economic development and destructive climate change. Other geoscientists, however, doubt they should declare this moment in time as the close of Holocene epoch, which demarcates the last 11,000 to 12,000 years of the current Quaternary period in geological time. Furthermore, they are reluctant to rule that the planet now is so fatally ensnared by rapid anthropogenic climate change that this new geological epoch of humanity's making, namely, "the Anthropocene" definitely exists. Such forced settlements do not adequately conform to the methodical practices of prevailing geoscience research; and, even if they did, few believe the declaration would make much difference in the workings of human life on Earth.

At the same time, the suggestive powers of the Anthropocene concept for many other intellectuals, scientists, and writers beyond the sciences have become almost irresistible (Lidskog and Waterton, 2018: 25-46). Its rapid proliferation in many cultural and scientific networks through their everyday spoken and written communication is a rolling daily plebiscite that leans toward ignoring the old rules. Professor Jedediah Purdy at Duke University's law school, for example, opines that human beings do, in fact, now inhabit "a new nature" since "the Anthropocene adds nature to the list of things we can no longer regard as natural," which transforms, in turn, the management of this "new nature" into "a political question because the Anthropocene future is, unavoidably, a collective human project" (Purdy, 2018). Soaking in the heated froth spraying from such rhetorical whirlpools, other thinkers also find an expansive remit to speculate more concretely about the current moment "as if" the Anthropocene epoch has become a reality during "the Great Acceleration" of economic and technological change since 1945 (McNeill and Engelke, 2014: 1-5). There are groups of museum professionals, who are also have decided to sail on this rhetorical tide by steering their institutions into the largely uncharted waters of these controversies (Newell, Robin, and Wehner, 2016; and, Möllers, 2013).

The catastrophic effects of rapid climate change are significant, and they do impact more than the taxonomic conventions of stratigraphers, geologists, or botanists about deep time. This study suggests nothing better exemplifies such add-on effects from these scientific debates than a few efforts by museums and other cultural institutions, first, to map new channels being cut by the currents churning up in debates about the Great Acceleration, and, second, to explore various rocks and ripples rising out of these discursive currents. Along the banks, one already finds some highly politicized collaborative conservation efforts at seed banks, zoos, biotic conservatories, aquaria, botanical gardens, and museums, as their curators struggle to sponsor the survival of Holocene life forms and cultural inventions as well as operate institutionally as arks for the activism needed to slow the accelerants of the 
Anthropocene.

This provisional analysis reviews these shifts in the workings of museums and other cultural institutions to decipher the politics and impact of Anthropocene narratives in "making culture" (Message, 2006; and, Hammond, 2018). Plainly, there are always unstable undercurrents in "the politics of display" (Macdonald, 1998) that cannot be avoided at museums. Moreover, exhibitions at zoos, museums, gardens or aquaria increasingly serve as "polemical fortifications, meant to hold ... the hearts and minds of visitors" (Luke, 2002: xviii). Still, the Anthropocene -- as a geological concept and a cultural meme -- has become a valid excuse for various cultural, historical, and natural heritage institutions to break with their conventions of epistemic discipline, upend ontological stabilizers, and reimagine political meaning at what might be the end of the Holocene.

As the Working Group on the Anthropocene, for example, gets closer to formal criteria to label this age still waiting to be officially named, the material indicators these authorities have adopted in their deliberations are fascinating. The significance of specific "golden spike" markers, like nuclear explosive isotopes, new technofossils (plastics, underground excavations, carbonaceous fly ash, etc.), and fossilizable biological remains (commercial livestock, domesticated avian species, disappearing megafauna, etc.) are being cited repeatedly as the more definitive markers of the Anthropocene turn by many studies. And, strangely enough, there are several cultural institutions standing-at-the-ready, which have anticipated the official advent of Anthropocene epoch by documenting the larger influence of such material markers (Zalasiewicz et al., 2017: 55-60). These developments deserve closer consideration.

Following a brief discussion that follows in Section I to contextualize the divisive debates about "the Holocene or the Anthropocene," Section II surveys a handful of museums and other heritage sites to depict how they are already serving as an inventive suite of displays for "remembering the Holocene" and "imagining an Anthropocene" -- in both scientific and cultural registers -- for the new collective understandings of historical time and human agency emerging around the Anthropocene concept.

First, with regard to the loss of Holocene megafauna and their environments, the discussion turns to the ark activism of "the Buffalo Commons" project in the American Midwest, which has aimed since the 1980s to restore "the sea of grass" and the buffalo herds that were nearly obliterated on the Great Plains during the nineteenth century. Second, it looks at a smaller, but more radical effort to resurrect lost megafauna and maintain ecosystemic services at "The Pleistocene Park" in the Russian Federation. The plan for this living landscape museum is to genetically reengineer extinct megafaunal species, like mammoths, to recreate the steppe ecosystem of the late Pleistocene epoch as well as forestall the melting of its permafrost substrata to slow global warming. Third, it turns to little known undersea heritage sites in the Western and Southern Pacific where hundreds of World War II sunken capital ships rest on the sea bottom in need of greater collaborative conservation. Many of them still entomb their crews and are regarded as national war grave sites. Yet, they are increasingly subject to illegal salvage operations to recover valuable metals. Fourth, with respect to "the Sixth Great Extinction" of biota during the last two or three centuries, it looks to the International Cryptozoology Museum in Portland, ME, which memorializes those losses, while advancing the credible need to defend unspecified wildlife that may not exist and/or has not been yet discovered. Fifth, in consideration of atomic energy being harnessed for military and civilian purposes, which has left extraordinary spikes in particular nuclear isotopes deposited all around the planet in water, soil, rock, and ice formations, it surveys these technological thematics at the National Museum of Nuclear Science \& History in Albuquerque, NM and the National Atomic Testing Museum in Las Vegas, Nevada. Sixth, the development of new plastics from fossil fuels is a significant marker of the Anthropocene, and they are examined briefly at the National Plastics Center and Museum now stored in Syracuse, New York. Seventh, the analysis moves to the National Agricultural Center and Hall of Fame in Bonner Springs, Kansas with its National Poultry Museum, because another highly distinctive marker of twentieth century life are the immense new middens of domestic avian bones around the planet. And, eighth, the Great Acceleration's growing alienation of human beings from Nature has coincided with a tremendous increase of "unidentified flying object" sightings and reports of alien species, which are now closely documented by The International UFO Museum and Research Center that has another unique perspective on the emergence of the Anthropocene.

Finally, Section III of this analysis concludes with thoughts about the significance of these institutions today. By serving as unusual sponsored sites of survival or unexpected clusters of collaborative conservation at the end days of the Holocene, they might provide the first foundations for the construction of a globally distributed Museum of the Anthropocene. As this new narrative colonizes more expert and popular understandings of the recent past, Anthropocenarian exhibitions undoubtedly will conserve and curate artifacts, materials, and sites from the Holocene epoch in the same dialectical fashion that "modern" museums of culture, history, nature, science, or technology 
all tacitly, and yet explicitly, have stood in contrast to the "pre-modern" nature, prehistory, society, superstition, or primitivism that their curators and visitors believed they had also eclipsed.

\section{The Holocene or the Anthropocene?}

At this contested conjuncture in historical and geological time, what should be the curatorial missions of cultural institutions beyond the traditional preservationist goals of museum, zoo, or botanic garden directors? For some, the Holocene is nearly lost or already gone. Consequently, some museum operations, explicitly or implicitly, approach the present-day as a lost heritage-in-the-making. That recognition, at the same time, turns them to engage as activists in the urgent tasks of rebranding their institutions as ecological arks, memory banks, biotic preserves, or marine micro-milieux. These managerial aspirations have been unfolding in bits and pieces since the 1980s and 1990s, but their importance acquires more urgency in the growing shadow of rapid climate change at this historical conjuncture (Crutzen and Stoermer, 2000: 17-18).

On the one hand, it is important to ask how should one appraise such curatorial aspirations in "the present(s)" of the Holocene and for "the future(s)" of the Anthropocene, which are being propounded in today's conflicted interpretations of this cluster of disruptive changes? In the long run, such shifts in natural history are ancient news. Extinction is normal, planetary catastrophes are nothing new, and geological epochs are, in fact, typified by new biota replacing older dominant biotic communities. On the other hand, many individuals and communities do feel endangered by these trends. Therefore, what specific cases of human/nonhuman life, organic/inorganic matter, or geological time/historical time should be spotlighted for inclusion in these Holocene heritage sites in light of the purported impact of the Anthropocene in the present, near future, and distant future (Anthropocene, 2013: 1-2)?

The world has been warned for decades about rapid climate change (Osborn, 1948; Commoner, 1971; and McKibben, 1989), but those warnings have been, and continue to be, ignored, downplayed, or belittled. To their credit, a few museum and other heritage studies professionals have anticipated this moment to examine the Anthropocene -- as the times foretold to be coming along with rapid climate change -- by putting these changes under scrutiny, in question, and on display. Beyond the usual activist pleas "to make a difference," however, many wonder if anyone really knows what difference can ever really be made.

In the minds of many, the Anthropocene thesis accurately captures how planetary-scale changes are being caused in “short-run' historical time by humanity's unintended irrational disruptions, as measured by civilizationendangering changes in the planet's air, water, soil, and biota, and they are then slowly registering materially in "long-run" geological time. As these trends advance, a planetary-scale infrastructuralization of the Earth (Luke, 2009b) deepens, and its networks of artificialized ecologies and naturalized economies (Easterling, 2014; and, 2001) essentially reveal a new dimension in dialectic of enlightenment that affirms development as disaster.

In that spirit, vested interests are busy calculating how this putative disaster is actually a great economic opportunity for advancing fresh schemes to truly rationalize Nature. Indeed, cli-fi dramas, high-tech utopias or ecological art works easily can pass as new ideologies of hope in the survivalist garb of eco-pragmatism, Whole Earth discipline or planetarian power for those who are "in the know." Even though Anthropocene-leaning narratives have floated around in arcane scientific debates since the 1970s or 1980s, Jameson slipped up when he did not add "the Anthropocene" as an exclamation point to his epilogue for modernity in Postmodernism, Or, the Cultural Logic of Late Capitalism. When he asserts, for example, "postmodernism is what you have when the modernization process is complete and nature is gone for good" (Jameson, 1991: x), he should have declared what you have is "The Anthropocene."

Once that insight was granted, its popularity has spread like a prairie fire. "The Anthropocene" concept becomes an all-purpose ideological license for intensifying greater human economic intervention in the environment (Steffen et al., 2011; and, 2015), even although such efforts really "do not change everything" (Klein, 2014). Nonetheless, these haphazard qualities in anthropogenic economic changes over the last 250 years are questioned with respect to their significance as definitive signals (Brown and Timmerman, eds. 2015) of either "the Holocene ending" or "the Anthropocene beginning," because the methodological practices of good geoscience, biophysics or climatology all warn today's impatient audiences that it frankly is too soon to tell. 


\section{Challenging Interventions}

The "exhibitionary complex" at work in many museums today also tracks the sovereign discretion of those powerful enough to disclose what might be imagined by whom, where, when, and how about rapid climate change and biodiversity loss. Cities, states, and cultural trusts beholden to coal, gas, and oil wealth still can feel such corporate powers withholding time, energy, and funding in these missions of disclosure, as they sponsor displays, for example, about how oil and gas are still the fuels of human progress and keys to individual wealth.

Believing these social forces will not continue to bias the presentation of cultural displays is unrealistic. Likewise, overdrawn efforts at representing how, when, and where "we" are steering nature's evolution, and all existing life forms often become grandiose. No matter how dire rapid climate change becomes, museums of art, culture, history, nature, or science at this turn in geological time will organize conflicted displays about carbon-based state sovereignty and its economic capability. At the same time, therefore, these larger social forces can bizarrely celebrate and condemn themselves in "open-minded exercises" of their resilient sustainable authority.

With so many different threats to life on Earth along the horizon, however, can the curators of the Holocene heritage also exhibit and interrogate some of the forces behind what is now at hand? The following sub-sections consider some of these efforts to highlight the unusual visions in existing displays as well as to question these experiments in need of greater curation, conservation, and care to teach humanity about this shift between two geological epochs.

\section{A. Returning the Buffalo to the Range}

The search for countervailing forces powerful enough to deploy against a corporate agrarian monocultures to defend biodiversity have been under consideration for years, if not decades (GPRC, 2014). One well-established program aims to restore the Great Plains of the United States to native grasslands with new large herds of buffalo (Matthews, 1992). This project for "rewilding" these ecologies with native species is a plausible solution (Ripple et. al, 2017) for rescuing and restoring North America's native grasslands as well as the aquifers beneath the surface (http://gprc.org/research/buffalo-commons/).

This ecosystem was destroyed rapidly in the nineteenth century as mostly white American settlers began enclosing these lands to eliminate the dominion of many Native American indigenous nations over much of the Plains. Their entire way of life was based on following the buffalo (Isenberg, 2000), but as white settler colonialism exterminated the immense herds of native North American bison it entailed the demise of Native Americans as well. Some Native American peoples had themselves only recently mastered control over this wide-open range by domesticating European horses introduced to the continent by the Spanish around 1500. Their dominance was soon undercut by settlers from Spain, England, Mexico, and the USA, who were intent upon putting the Plains to the plough, replacing bison with cattle, creating new towns and cities, and eventually crisscrossing these territories with railroads, fencing, roads, and telegraph networks. Once numbering around 60 million in North America during the fifteenth and sixteenth centuries, less than one thousand bison remained by 1900 in the USA (Isenberg, 2000).

The industrial agrarianization of the Plains after 1865 by small-holding farmers and ranchers rose and fell with the vagaries of commodity prices, labor supplies, water sources, and government agents (Krueger and Globe, 2007; Lind, 2013; and, Ordway, 1953). Between the 1890s and 1920s, this unsustainable mode of production peaked as larger corporate producers displaced small-holders (Berry, 1977) and degraded the soil. During the Great Depression, many towns stagnated, farms were abandoned, labor migrated to larger cities, but decades of massive alterations in soil deposition, water use, and land management had qualitatively altered the Plains' ecosystems, water courses, and land itself (Popper and Popper, 2004) for the worse.

With architects today designing vertical food gardens into urban buildings, agriculture moving into controlled suburban environments, and traditional family farms failing after the 1970s out on the Plains, it has become clear that other options exist to feed people. As Callenbach (1996) asserts, the best possible rescue for the Great Plains was, and to an extent still is, returning to a "buffalo commons" to restore the land, even as climate change alters the region's weather, vegetation, and animal life. This hope was sparked as native bison populations that grew from around 20,000 in 1950 to over 360,000 in the 2000s. Creating an "American Serengeti" devoted to caring for lost North American, displaced Mesoamerican, or even rescued sub-Saharan African biota all have been proposed, prototyped, and readied for practice. For many areas of the Midwestern states, this proposal is alluring as they face more human population losses, rezoning for massive installations of renewable energy plants with hundreds of 
huge wind turbines, and a future in which human depopulation would go hand-in-hand with the decarbonization of the economy (Samuels, 2011). While today's museums about the Old West often depict the end of the trail for "the buffalo" around 1900, these new heritage planners are scheming proactively to mitigate the Anthropocene by restoring its native wild ruminant herds by 2100 to reawaken its Holocene landscapes.

In such a shift, the required species can be revived from small bison populations in North America, hybridized from existing exotic offshore bison populations or even supplemented with new species relocated from disappearing biomes in Africa, South America, or Asia. Each of these changes would justify launching new scientific expositions worthy of documenting this radical experiment in revitalizing lost ecologies. Another Holocene heritage question that demands answers is what would be the fate of the settler colonialist biota of the Old West that now are more recent hybrids facing depopulation here in the Anthropocene, because they too are now no longer as valued -- wild mustang horses, range adapted cattle strains from Europe, domestic barnyard chickens, draft horses, industrial hogs, or imported sheep?

By dedicating a handful of ranches and farms to preserve these aspects of the Holocene as nineteenth century American heritage sites with such industrial biota, the Great Plains could add yet another hall of heritage to curate for its museums of the Anthropocene, even as twenty-first century genetic engineers recall from the dead, or near extinction, once well-adapted native bison populations on the Plains. Other zones could harbor easily adaptable OldWorld species needing their own refuges for survival as African megafauna are displaced by the continent's growing human populations. Amidst hundreds of wind farms, solar energy plants, and abandoned towns, roads, and farms, the Anthropocene in this region would dawn as localized geoengineering a landscape that quilts together in America fragments of New Spain returned to the 1760s, vestiges of America's frontier Old West, and bits of 1950s wild Africa relocated in America by the 2060s under the curatorial care of a new multistate Holocene heritage authority (Allenby, 2005; Hinchliff, 2006; and, Heck and Rogers with Carroll, 2014).

\section{B. Back to the Pleistocene and Reshaping the Anthropocene}

Another living landscape museum with even greater ambitions is a plan to build amid the ruins of the world's other failed Cold War superpower, the Russian Federation, a highly imaginative "Pleistocene Park" (www. pleistocenepark.ru/en/) as an ark to cross time and space. As Witcomb (2003) observes, the Great Plains Buffalo Commons "rewilding" expo could definitely move the museum beyond the rhetorical register of a mausoleum by resurrecting a relic species. To mitigate the Earth's rapid climate change, the Pleistocene Park's proponents, however, want to be more radical by reviving a massive sub-Arctic biome of grasslands on Siberia's thawing permafrost among its vast arboreal forests for other lost species. This goal might be hard to attain in a time when CO2 levels stand at 400 ppm plus, since these greenhouse gas (GHG) levels during the last ice ages of the Pleistocene were less than 220 ppm. Nonetheless, this de-extinction project aims to introduce resurrected mammoth herds into this ecosystem. By mixing genetically reengineered mammoth DNA with contemporary Asian elephants' gene pools and/or geneediting the current species of Asian elephants to express adaptive new traits, like longer hair, more body fat, smaller ears and some other physiological tweaks controlled by less than 50 genes (Andersen, 2017), these genetic engineers hope to accustom these mammoth-like chimeras to the sub-Arctic. Along with these neo-elephantine variants of extinct megafauna, the main advocate for this living zoological expo, Sergey Zimov, also is intent upon reviving other extinct wild horse, moose, reindeer, muskox, elk, and bison populations upon the huge natural ranges they occupied during the late Pleistocene and early Holocene (Davletyarova, 2013). If their work would slow the concentration of CO2 and the release of methane trapped in the region's soils, then it is regarded as well-worth trying for these outcomes alone.

A restoration of the mammoth steppe ecosystem, like the buffalo commons in North America, is promoted as a heritage project, an ecosystem restoration, a climate change adaptation, a genetic engineering experiment, and ultimately a new destination tourism site for a "World Made by Man," only now truly by design (Zimov, 2005) by preserving early Holocene life forms. While the entire ecosystem of 2.6 million years ago is unlikely to be fully restored, especially with the Great Acceleration's massive GHG forcing since 1980, the prospect of emulating partial swaths of it with Holocene forests and taigas in Siberia, Alaska, or the Yukon as "a mammoth steppe" is a comparatively low-tech option. If this experiment succeeded, considerable curation and conservation would then be required to care for this Holocene heritage park as a modernizationist ecological and educational experiment (Hanford, 2015). This venture also crystallizes, however, the cultural and political complexities involved in reimagining the future for human inhabitants around museums, communities, and cultures dependent upon rapid climate change (Newell, Robin, and Wehner, 2015). 
Even though the Arctic Sea ice retreats further each year, Zimov's faith in returning seriously cold conditions to the Earth's polar regions remains alive. Beyond possibly limiting GHG emissions, the Pleistocene Park also challenges the definitions of biodiversity in treating the ecosystems of the sub-Arctic tundras as ecosystems in need of ecosystemic servers to restart of some of the Earth's ancient biomes as generators of greater environmental services. Resurrecting mammoths, redesigning Asian elephant species, and relocating vast herds of celebrity biota from tiny heritage populations around the world sounds plainly somewhat implausible. Yet, it would serve to organize another hall for the Holocene in a nascent museum complex for the Anthropocene by assembling lost pieces of the Pleistocene with healthy hunks of the Holocene in a geotechnic experiment working to adapt to the Anthropocene.

\section{Shielding the Honored Dead from Dishonorable Salvaging}

Another fascinating turn in the institutional, political, and physical boundaries of the Holocene, which clearly do require many parallel sites of curation, preservation, and remembrance to document, can be found amid many historically significant World War II artifacts across the seascapes and ocean bottoms of the Eastern Pacific. Recent archeological, historical, and military surveys there have located hundreds of sunken Allied and Axis World War II-era warships, but these studies also have discovered at least 35 to 40 major capital ships have been disturbed by illegal salvaging operations. These World War II vessels mark, or actually still contain, the remains of thousands of American, Australian, British, Dutch, Japanese and other combatant nations' servicemen, which grants them the status of national war graves. Nonetheless, the corroded wreckage of such 70 to 75 -year-old ships are being partially or completely salvaged to be sold "as scrap, but the ships also contain valuable metals such as copper cables and phosphor bronze propellers” (Holmes, Ulmanu, and Roberts, 2017).

More significantly, thousands of tons of material in these sunken ships are extremely rare commodities in the era of the Great Acceleration due to a common quality, namely, it is "steel plating made before the nuclear testing era, which filled the atmosphere with radiation. These submerged ships are one of the last sources of 'low background steel," virtually radiation-free and vital for some scientific and medical equipment" (Holmes, Ulmanu, and Roberts, 2017). While some of the salvaged ships are more minor vessels, such salvaging has damaged even the larger iconic ships of tremendous national significance, like Great Britain's HMS Repulse and HMS Prince of Wales, Australia's HMAS Perth, and the USA's USS Houston. These ships were key elements in historic World War II battles, like the decisive attacks by the Imperial Japanese Navy Air Service on the Repulse and Prince of Wales, which sank in minutes on December 10, 1941 during what many regard as Great Britain's "Pearl Harbor."

Such scrap metal salvaging might seem utterly implausible and unprofitable. In fact, these wrecks are artifacts with considerable monetary value. "Having been and lost before any nuclear weapons explosives were detonated during and after 1945, their metal components can be certified as "low-background" materials, which "makes even small quantities that have survived the salt water extremely useful for finely calibrated instruments such as Geiger counters, space sensors, and medical imaging" (Holmes, Ulmanu, and Roberts, 2017). Beyond these exotic materials, the growing demands across Asia, especially China, for scrap metal makes these sites worth disturbing with deepwater equipment. As the world economy improves, even poor-quality steel can bring about $£ 1 \mathrm{M}(\$ 1.3 \mathrm{M})$ per ship, according to some estimates, especially with the added brass from pipework, valued at $£ 2000$ a ton, and copper wiring, roughly $f^{5}, 000$ a ton (Holmes, Ulmanu, and Roberts, 2017).

Such hulks sit at the outer limits or margins for official heritage projects, because only walls of basic morality and weak international law protect them. Lost first in action or by accident in wartime during sea attacks, massive storms or operational mishaps, these ships remain historically important. Existing maritime laws as well as international ethical traditions classify wrecks as protected sites out of the respect to their lost crews. Whether Allied or Axis vessels, the standards for preserving such sites have been absolute.

Malaysia, Indonesia, and the Philippines, however, also seem unwilling to prevent pilfering of these historical relics and war graves, which are (as the United Kingdom's Defense Ministry has declared) internationally protected: "a military wreck should remain undisturbed and those who lost their lives on board should be allowed to rest in peace" (Holmes, Ulmanu and Roberts, 2017). Despite such declarations, sunken vessels like the Perth, which displaced nearly 7,000 tons, had a beam of 57 feet, and measured over 560 feet long, is now 60 to 70 percent gone, while the Repulse and Prince of Wales are heavily damaged, and the Houston also shows signs of being repeatedly plundered (Holmes, Ulmanu, and Roberts, 2017).

These clusters of sunken ships from World War II are furthermore suggestive instances of how the museum's traditional divisions of nature/culture, human/nonhuman, living/nonliving, inside/outside or open/closed can 
become muddled, and then violated to a significant extent, by material realities at the turn of the Holocene. Cultural objects, once left in common trust at the bottom of the sea, no longer are regarded as resting in a trustworthy vault for both treasured machinic objects and revered lost servicemen that deserve complete respect.

Such nonliving individuals and revered naval vessels physically are beyond the display spaces of any conventional museum, but such sea bottom sites are an important historic archive. They can be visited by divers or remotely piloted submersible vehicles, either to examine their archeological treasures or to pay respect to fallen seamen, which keeps these sites alive in the world's collective memory. While the conditions of the Anthropocene rend many conventional museumological distinctions for those concerned with the curation, conservation, and care for such historical treasures, they clearly belong in the Holocene heritage collection.

\section{Caring for Hidden Biota}

With the growing losses being incurred daily in the current on-going Great Extinction, the trails blazed by the International Cryptozoology Museum also will need to be widened and extended ( http://www.cryptozoologymuseum. org) to preserve elements of the Holocene. Whether the species of cryptozoa are hidden, lost or never-to-bediscovered, zoological orders of living fossils, extinct species, mysterious cryptids (The Sasquatch, Yeti, Loch Ness monster, Tatzelwurm), and soon "de-extincted" chimeras clearly need to be documented. On the one hand, their discovery, if possible, is important in its own right. On the other hand, their disappearance is another mark of rapid climate change as well as bigger disruptions in habitats for the Earth's biota at this turn from the Holocene to the Anthropocene. All of the species already lost to extinction since the 1760s or 1940s perhaps somewhere wish that they too had been lucky enough to remain cryptids rather than be reduced to fanciful simulations, stuffed carcasses, preserved feathers or skeletal displays found in this small museum.

The launch of the International Cryptozoology Society in 2016 in association with the International Cryptozoology Museum, even if partly in jest, in Portland, Maine then should not be ignored. The discovery of new animals, like a non-extinct living coelacanth during 1939 by a trawler in South African waters may still occur in the coming decades. While its basic form evolved 400 million years ago, the divergence of the Tanzanian and Comorian coelacanths around 200,000 years ago coincided oddly enough with advent of the first homo sapien groups also in Africa (Brouwers, 2012). Documenting whatever new orders and genera of sociocryptozoa that might be declining or disappearing around us also needs to begin as species of life that once existed on the Earth. Likewise, growing creationist movement to resurrect extinct species as bioengineered copies or genetically modified chimeras also should be added to the halls of the International Cryptozoology Museum as the twenty-first century continues.

Still living, but once cryptid, the coelacanth fish species evaded documented human awareness for 2000 centuries, so the science of the twentieth-century could do much to alert the Anthropocene future with a Holocene biotic survey to anchor the zoological mission taken upon by this cryptozoological society and museum. Humans coexist today with many other biota basically unchanged for many millennia, ranging from the tuatara (200 million years), horseshoe crab (450 million years) giant Chinese salamander (170 million years) and nautilus (500 million years). Yet, the destructive wake of The Great Acceleration is leaving some species, including the nautilus, giant Chinese salamander or tuatara far more endangered than ever. With rapid climate change and habitat loss, their nearly cryptozoological status could become complete as these paleontological relics become the latest ghosts from the Holocene.

\section{E. Explosive expositions}

The National Museum of Nuclear Sciences History ( http://www.nuclearmuseum.org/see/exhibits) is another benchmark for imagining any exhibition of the Holocene at the dawn of the Anthropocene. Located in Albuquerque, NM just off I-40 and not far from the Trinity Test Site and the Los Alamos National Lab, its displays depict many facets of American, and global, nuclear history, ranging from a profile of uranium and nuclear power, a kid-friendly Albert Einstein's lab, Radiation 101, Hiroshima and Nagasaki, The Cold War, Atomic Culture/Pop Culture, and most significantly, "The Decision to Drop" that examined "the testing of the world's first atomic bomb" to illustrate to visitors "just how much influence over the modern world this test created" ( http://www.nucearmuseum.org/see/ exhibits).

Stratigraphers agree that the most definitive marker of the Anthropocene's advent is the intense deposition of nuclear isotopes around the world from 1945 to 1963 when the great powers tested, dropped, and then continuously tested in the ocean, atmosphere, and deserts of the world hundreds of atomic and thermonuclear devices. On this 
point, one might recall the lost seamen on the HMS Prince of Wales who could not have imagined this vessel and their graves would be robbed simply to save the vessel's armored steel plates still free from these radioactive contaminants. This museum omits the Anthropocene sidebar, but it does indirectly flag it by giving "its visitors a memorable and vivid understanding of nuclear science and history" ( http://www.nuclearmuseum.org/see/exhibits).

This message is underscored more directly at the National Atomic Testing Museum (NATM) in Las Vegas, NV. Still, this very focused institution also ignores the larger terrestrial history of the Holocene. Its mission is to focus solely on "lessons of the past and present to better understand the extent and effect of nuclear testing on worldwide nuclear deterrence and geo-political history” ( http://www.nationalatomictestingmuseum.org/about/).

By highlighting the quick construction and long years of use of the Nevada Test Site, the museum's main feature focuses on a key source of the markers chosen to date the Anthropocene, namely, the highlights behind "20 years of nuclear testing" ( http://www.nationalatomictestingmuseum.org/about/ ) with its six main permanent exhibits: Ground Zero Theatre (to experience a simulated atmospheric atomic blast), Atmospheric Testing Experience (a simulation of an atmospheric nuclear bomb detonation), Radiation (to discover how natural and man-made radiation is tracked, monitored, and measured), Underground Testing (how and why testing when underground), and Atomic Culture (the still strange lessons for school children in the 1950 s about how to "duck and cover" while learning to survive in the Atomic Age). Those living in 2100 will need these displays for both curation and conservation, given how this Las Vegas site exemplifies how a wholly deadened landscape from the Holocene should serve as a museum.

\section{F. Plastics are the Future}

During the 1960s, the world was told "one word: Plastics" in a popular American film "The Graduate," because "there's a great future in plastics." Plastics indeed have proven to be "the future" for humanity. Still, the National Plastics Center \& Museum (NPCM) in Leominster, MA, which opened during 1972, had to close in 2008 due to financial difficulties and low traffic counts during its operation. Set up with the support of Modern Plastics World (MPW) magazine along with the Society of Plastics Engineers, The Plastics Pioneers, and the NPCM Foundation, the Museum also housed The Plastics Hall of Fame "to honor professionals who have made significant contributions to the advancement of the industry" ( https://www.plasticstoday.com/content/national-plastics-center-museumshutting-its-doors/46023220211582). Despite the off-shoring of many factories, the plastics business is still the third largest manufacturing industry in the USA, and its products have been adopted as another distinctive marker of the Anthropocene.

From the first non-organic mass market plastics sold widely in the 1930s through today's fossil fuel-based plastic-wrapped modernity, the deposition of plastic particles in the Earth's land and waters is leaving another eternal sign of humanity's impact on Nature. While the museum's artifacts can still be visited in the library of Syracuse University, billions of tons of plastics are viewable everyday around the Earth. From the Great Plastic Gyres in the Atlantic and Pacific Oceans to effluvia of plastic trash flowing out of the world's major rivers, plastic debris now blankets the planet's seas. At the convergence of the Arctic Ocean with the planet's super- and sub-tropical zones of sea water, there are detrital thick clots and thin layers of plastic that stretch for hundreds of miles ( https://www. nationalgeographic.org/encyclopedia/great-pacific-garbage-patch ). While these disturbing phenomena alone are impressive, this material is continuously and dangerously degrading into smaller pieces until birds, fish, crustaceans, and other sea life ingest the tiny particles. Such molecular compounds are essentially timeless and are turning up in marine bottom sediments on their way to petrification. In addition, millions of tons of plastic microfibers are entering the environment from washed clothing with plastic fabrics along with millions more tons of plastic microbeads from cosmetics and cleaning supplies (Laville, 2017). While not entirely dead, this hybrid water/air/ trashscape is a growing environmental achievement from the late Holocene in need of considerable curation and care as many bizarre species of life now are colonizing these floating archipelagos of manufactured rubbish, while their showers of pollutants exterminate many crucial marine species.

\section{G. The Distinctive Fauna of the Anthropocene}

The other distinguishing twentieth-century marker of the Great Acceleration into the Anthropocene is the exponential increase in domesticated poultry populations. Produced on an industrial scale, chickens especially are the most favored animal protein for humans worldwide, creating huge middens of chicken bones in garbage dumps and municipal waste sites. Knowing this, one must turn to the National Agricultural Center and Hall of Fame in Bonner Springs, KS with its National Poultry Museum (www.aghalloffame.com). 
Located just outside of Kansas City, KS, the museum has several matter-of-fact, almost vernacular culture exhibits on geese, ducks, turkeys, and chickens to display the growing importance of select breeds in meeting the nation's and world's need for broilers, eggs, and wings by the millions daily. Looking at issues of chicken feeding, health, marketing, reproduction, processing, and production, the museum strangely interweaves the corporate lives of chickens and humans in the USA as an extraordinary achievement of high modernity in accord with it's archival and institutional ties to the American Poultry Historical Society, Inc. (http://poultryhistory.org/index.html). Meant to house significant agro-industrial artifacts, it also "tells the story of the American poultry industry over the last two centuries" (Schleicher, 2009) as it tacitly morphs into this Anthropocenic assemblage at the close of the Holocene.

With commercial hatcheries, mechanical incubators, and artificial insemination, the museum presents the blueprints for how corporate capital continues to engineer processed protein units that remake humanity and nature, while labelling all of it the "Evolution of an Industry" (Poultry World, May 8, 2009). Of course, geese, ducks, and turkey also are reduced to comparable species of monstrously homogenized chunks of flesh suitable for frozen shrink-wrapping, but the curation and care of these avian artifacts mainly concentrates on the chicken whose bones are now the most common and concentrated deposits of contemporary techno-fossils piling up in dumps all around the world. Fans of the celebrity cryptids, like the Himalayan Yeti or Northwestern Sasquatch, might believe that industrial poultry breeds are attractive snacks for their beasts, but the toxic accelerated breeding of such poultry stocks also is effacing the wild nature where such cryptids really could roam.

\section{H. The International UFO Museum and Research Center}

Like alien space invaders, the Anthropocene has been sighted many times, speculated about endlessly, embraced by many heart and soul, but the evidence for many audiences is still scanty and suspect. There is no reason, however, that any one of these other museum-like operations on the Great Plains, in Russia, across the Western Pacific or elsewhere in the USA near Alamogordo, NM, Yucca Flat, NV, Leominster, MA or Bonner Springs, KS, should be able call out first dibs on serving as the exemplary origin point of the Anthropocene. In fact, there are maybe even more edifying municipal possibilities for this distinction, like Roswell, NM, which is home base for The International UFO Museum and Research Center.

Founded by Walter Haut (a public information officer at Roswell Army Air Field during the famous "1947 Roswell Incident") and Glenn Dennis (a Roswell Incident participant), this marvelous institution was set up, and then opened as the International UFO Museum \& Research Center in 1992. The volume of visitors over the past 25 years forced the museum to move into its now third expanded location in the former Plains Theater on North Main Street in Roswell, and "the number of visitors continues to be the envy of many other tourist attractions in the state" (www.roswellufomuseum.com/).

Since 1996, an annual Roswell UFO Festival also pulls even more visitors into town, making UFOs one of Roswell's main economic engines for burning oil, using plastics, cooking chickens, and searching for exobiological cryptozoa. Indeed, as the UFO Museum curators note with pleasure, "while in Roswell, most visitors at least buy gas and a soda, or they may spend a week learning about the phenomena [of UFOs] and Roswell" ( http://www. roswellufomuseum.com/museum/museumhistory.html). The Anthropocene, if it is to serve as "a warning to the world," as Paul Crutzen claims, must gain popular momentum as a cultural trope equal to these UFO displays about the alleged 1947 crash of an alien spacecraft outside of Roswell. If it is, then many Roswell residents would affirm to all the Earth's living landscape expositions, odd museums, and botanical preserves that they should hope they have it this good. Strangely enough, the UFO museum also was set up, in part, as a "warning to the world" about the presence of alien beings coming from outer space to destroy the Earth during the late Holocene. Rarely seen since 1947, according to the UFO culture industry that has colonized Friday nights on The History Channel by tracking down how most of ancient world history also appears to be the work of alien beings, these exobiotic beings apparently have realized that humanity already has done the key terraforming work of their alien invasions for them.

In many respects, all eight of these unusual exhibitionary enterprises should be linked to a distributed "Museum of the Anthropocene," and their respective advocates could mobilize this contested meme in these Halls of the Holocene that would bring this educational display into being. Each site reflects upon its specific meanings, refracts particular interpretations for closer consideration, and, in some instances, rechannels the questions raised by the Anthropocene -- as a scientific and cultural narrative -- to spark some strategies for significant agency in projecting human, nonhuman and posthuman imaginaries of past, present, and future Earth conditions for yet-to-be-opened museums to transport visitors into these galleries of lost, or never-to-be-found, Holocene ways of life. 
All of the eight institutions discussed here, to a significant extent, are remaking culture (Message, 2006) with varying Anthropocene narratives that complicate the particular distinctions drawn during the Holocene between raw nature, human culture, and terrestrial history (Jacobs, 1985; MacKaye, 1968; Fuller, 1962; Weber, 1958; and Giedion, 1948). Inasmuch as the world, which could be defined as the "biosphere" and "noosphere" (Vernadsky, 1945 ) made by humans since the 1760 s or 1940 s, is an unstable amalgam of contradictory trends, it is almost beyond belief to pretend that humans ever have it all "under control." Instead it is being made, and increasingly occupied, in the displaced registers of processed nature, posthuman culture, and machinic history in artificial assemblages that unfold around/through/with humans, but not always in accord with their close control, direct design, or enlightened engagement (White, 1996; Cronon, 1992; and, Haraway, 1991). Any of these still fairly minor cultural installations could be an affiliated hall of disclosure for an authoritative Museum on the Anthropocene still to come, since most existing museums of history, science, technology, or nature might well need to be retitled at some point as Museums of Holocene History, Botanical Gardens of Holocene Flora, or Zoological Museums of Holocene Fauna.

\section{Concluding Thoughts}

Most existing Anthropocene discourse -- both inside and outside of museums -- is hyperbolic as it struggles to close out the books on the Holocene. Divisive disciplinary debates happen in many fields of intellectual work, and a widespread ideological insurrection is indeed erupting in the academy to make the Anthropocene brand a far more popular marque (Klein, 2014; Kolbert, 2014; Cohen, 2014; and, Evans and Reid, 2014). On one level, the Holocene is still coterminous with essentially most of the rapid changes attributed to the Anthropocene during the Great Acceleration, and the gaps could easily be addressed with simply having sub-divisional ages or stages in the Holocene to account for the increasing dominance of human beings in shaping the environment during and after the Neolithic Revolution. Such variations exist in many earlier epochs in accord with the growing evidentiary materials this or that scientific community regards as most determinate. Those debates are still on-going, but they also antedate the imperatives behind adopting the Anthropocenarian brand that Crutzen and Stoermer aggressively touted in 2000.

On a second level, the ideological agenda of Anthropocenarian networks is to change "the naming game" by using the suspected cause of massive change, namely, "Humanity," as its brand marker for this epoch. Crutzen, in particular, is taken with comparing humanity to the planetary disasters incurred by the Earth over deep time, but no other era is named by geoscience, for example, the Asteriodocene, Vulcanocene, or Methanocene in the current scientific literature. This is not to say the global disaster taxa taking hold during the Great Acceleration, the Industrial Revolution, or the Neolithic Revolution are entirely ignored; but one species -- Homo sapiens sapiens -- is being privileged with unusual alacrity in branding this contemporary stratigraphic controversy (Bostic and Howey, 2017).

Deep temporal terms are being twisted to match up with the recent relics of human spatiality piling up in the planet's soil, ice, stone, and botanical records. As the human presence spreads, it also makes much easier to dig the looming Anthropocene future out of the still Holocene present (Orwin, 2016). Lefebvre (2003) speculates all spatiality must be understood as the articulation and materialization of social practices, political powers, and cultural programs. It is continuously produced in subjective life rather than naively discovered as objective properties in the volumes, surfaces, and expanses of ordinary encounters with waters, skies, or lands. The Anthropocenarians, however, turn Lefebvre on his head inasmuch as they assert these ordinary encounters with the atmosphere, hydrosphere, lithosphere or cryosphere, as natural space, are now historically distinctive (Higgs, 2003). Because they hope to brand humanity's social relations deeply in history, they must seek definitive signs of it becoming materially embedded in deep geological time to legitimate these scientific politics (Luke, 2017).

Ultimately, Crutzen concedes the contestedness of this nascent reality with regard to defining the Anthropocene. For him, uncertainty is what actually holds true: "The Anthropocene, what is it, really? Nobody yet knows" (Crutzen cited in Schwägerl, 2014: 219). His branding aspirations to make it the deepest ecology defined by humanity have been, in a sense, realized since 2000. Believing "the Anthropos" of recent fossil-fueled history is the cause of radical geologically documentable events is an easy conversion, transforming faith into fact for expert and layperson alike.

For reasons to be determined, ranging from nuclear war to an as yet-to-be-detected massive asteroid headed straight at the Earth, the Holocene might end tomorrow. All humans could die off, and this artificial world would disintegrate in some unknown post-Holocene conditions in another deep geological time. Meanwhile, those tending to the conservation and care for the Holocene, as heritage in these times of ecological upheaval, must grapple 
with many possible outcomes in shallow historical time. Beyond these scientific politics, the planet will survive, life will adapt in some fashion, and then other dominant sapient beings could then well thrive. In the meantime, radical interventions are pushing museum-grounded practices to engage inventively with these political realities. Such efforts are important to get beyond the happy homilies of resilience and demonstrate that nothing guarantees a bright and sunny ending before museum visitors leave the building. Doing something is better than nothing, but nothing yet seems to be getting better when it comes to rapid climate change. Regardless, these protracted ethical and political struggles over the narrative constructions of the Holocene or the Anthropocene also are no excuse for permanent gloom. Instead, like many others before it, these battles are tests, as Gramsci would agree, that demand, "pessimism of the intellect, optimism of the will."

\section{References}

${ }^{*}$ A much longer draft version of this paper was presented at "Remaking the Museum: Curation, Conservation, and Care in Times of Ecological Upheaval," Centre for Environmental Humanities, Aarhus University, Aarhus, Denmark, December 6-7, 2017

Allen, John and Nelson, Mark. 1989. Space Biospheres. Oracle, AZ: Synergetic Press.

Allenby, Braden. 2005. Reconstructing Earth: Technology and the Environment in the Age of Humans. Washington, DC: Island Press.

Andersen, Ross. 2017. "Welcome to Pleistocene Park," The Atlantic, (April) (https://www.theatlantic.com/magazine/ archive/2017/04/pleistocene-park/517779).

Anthropocene. 2013. "Editorial," Anthropocene, 1: 1-2.

Berry, Wendell. 1977. The Unsettling of America: Culture \& Agriculture. San Francisco: Sierra Club Books

Bostic, Heidi and Howey, Meghan. 2017. "To Address the Anthropocene, Engage the Liberal Arts," Anthropocene, Vol. 18 (June): 105-110.

Brown, P. and Timmerman, P. 2015. Ecological Economics for the Anthropocene. New York: Columbia University Press.

Brouwers, Lucas. 2012. "Coelacanths are not Living Fossils. Like the Rest of us, they Evolve," Scientific American (February 6) (https://blogs.scientificamerican.com/thoughtomics/coelacanths-evolve-indian-ocean-is-home-to-distinct-populations).

Callenbach, Ernest. 1996. Bring Back the Buffalo: A Sustainable Future for America's Great Plains. Berkeley: University of California Press.

Cohen, Jeffrey Jerome. 2014. Prismatic Ecology. Minneapolis: University of Minnesota Press.

Cronon, William. 1992. Nature's Metropolis: Chicago and the Great West. Norton: New York.
Crutzen, Paul and Eugene F. Stoermer. 2000. "The Anthropocene," Global Change Newsletter. 41:17-18.

Davletyarova, Damira. 2013. "The Zimovs: Restoration of the Mammoth-For an Ecosystem, and Reversing Global Warming," Ottawa Life Magazine, (February 11) (http://www.ottawalife. $\mathrm{com} /$ article/the-zimovs-restoration-of-the-mammoth-era-ecosystem-and-reversing-global-warming? $\mathrm{c}=9$ ).

Easterling, K. 2014. Extrastatecraft: The Power of Infrastructure Space. London: Verso.

Easterling, Keller. 2001. Organization Space: Landscapes, Highways, and Houses in America. Cambridge, MA: MIT Press.

Evans, Brad and Julian Reid. 2014. Resilient Life: The Art of Living Dangerously. Cambridge: Polity Press.

Fuller, R. Buckminster. 1962. Untitled Epic Poem on the History of Industrialization. New York: Simon and Schuster.

Giedion, Siegfried. 1948. Mechanization Takes Command: A Contribution to Anonymous History. New York: Norton.

Great Plains: Restoration Council (GPRC). 2014. (www.gprc. org/research/buffalo-commons).

Hammond, Andrew. 2018. "Deciphering museums, politics, and impact," British Politics. https://doi.org/10.1057/ s41293-018-0086-8

Haraway, Donna. 1991. Simians, Cyborgs and Women: The Reinvention of Nature. New York: Routledge.

Heck, Stefan and Matt Rogers with Paul Carroll. 2014. Resource Revolution: How to Capture the Biggest Business Opportunity in a Century. New York: New Harvest/ Houghton Mifflin Harcourt.

Higgs, Eric. 2003. Nature by Design: People, Process, and Ecological Restoration. Cambridge, MA: MIT Press.

Hinchliff, Steve. 2006. "Reconstituting Nature Conservation: Towards a Careful Political Biology,” Geoforum, 39: 88-97. 
Holmes, Oliver, Ulmanu, Monica, and Roberts, Simon. 2017. "The World's Biggest Grave Robbery: Asia's Disappearing WWII shipwrecks," Guardian, (November 2). (https://www. theguardian.com/world/ng-interactive/2017/nov/03/worldsbiggest-grave-robbery-asias-disappearing-ww2-shipwrecks).

International Cryptozoology Museum. 2017. (http://www.cryptozoologymuseum.com).

International UFO Museum \& Research Center. 2017. (www. roswellufomuseum.com/index.html).

Isenberg, Andrew C. 2000. The Destruction of the Bison: An Environmental History, 1750-1920. New York: Cambridge University Press.

Jacobs, Jane. 1985. Cities and the Wealth of Nations: Principles of Economic Life. New York: Vintage.

Jameson, Frederic. 1991. Postmodernism, Or, the Cultural Logic of Late Capitalism. Durham, NC: Duke University Press.

Klein, Naomi. 2014. This Changes Everything. London: Allen Lane.

Kolbert, Elizabeth. 2014. The Sixth Extinction: An Unnatural History. New York: Henry Holt.

Krueger, Rob and David Globe. 2007. The Sustainable Development Paradox: Urban Political Economy in the United States. New York: Guilford Press.

Laville, Sandra. 2017. "Stella McCartney calls for Overhaul of Incredibly Wasteful Fashion Industry, Guardian (November 28) (https://www.theguardian.com/environment/2017/nov/28/ stella-mccartney-calls-for-overhaul-of-incredibly-wasteful-fashion-industry?utm_source $=$ esp\&utm_medium $=$ Email\&utm_ campaign $=\mathrm{GU}+$ Today + USA +-+ Collections $+2017 \&$ utm_ter$\mathrm{m}=254401 \&$ subid $=19974816 \& \mathrm{CMP}=\mathrm{GT}$ _US_collection).

Lefebvre, Henri. 2003 [1971]. The Urban Revolution. Minneapolis, MN: University of Minnesota.

Lidskog, Rolf and Waterton, Claire. 2018. "The Anthropocene: A Narrative in the Making," Environment and Society. https:// doi.org/10.1007/978-3-319-76415-3_2

Lind, Michael. 2013. Land of Promise: an Economic History of the United States. New York: Harper.

Luke, Timothy W. 2017. "Reconstructing Social Theory and the Anthropocene," European Journal of Social Theory, 20 (1): 80-94.

Luke, Timothy W. 2009b. "Developing Planetarian Accountancy: Fabricating Nature as Stock, Service, and System for Green Governmentality," Current Perspectives in Social Theory, 26: 129-159.

Luke, Timothy W. 2002. Museum Politics. Minneapolis: University of Minnesota Press.

Macdonald, Sharon. 1998. The Politics of Display: Museums, Science, Culture. London: Routledge.
MacKaye, Benton. 1968. From Geography to Geotechnics. Urbana: University of Illinois Press.

Matthews, Anne. 1992. Where the Buffalo Roam: The Storm over the Revolutionary Plan to Restore America's Great Plains. New York: Grove Weidenfeld.

McKibben, Bill. 1989. The End of Nature. New York: Random House.

McNeil, J. R. and Peter Engelke. 2016. The Great Acceleration: An Environmental History of the Anthropocene Since 1945. Cambridge, MA: Belknap/Harvard University Press.

Message, Kylie. 2006. New Museums and the Making of Culture. New York: Berg.

Möllers, Nina and Herkl, Wolfgang M. 2015. Welcome to the Anthropocene: The Earth in Our Hands. Munich: Deutsches Museum.

Möllers, Nina. 2013 "Cur(at)ing the Planet-How to Exhibit the Anthropocene and Why," Anthropocene: Exploring the Future of the Age of Humans: Rachel Carson Center Perspectives: Transformations in Environment and Society, ed. Helmuth Trischler. No. 3, 57-66.

Newell, Jennifer, Robin, Libby, and Wehner, Kirsten. 2016. Curating the Future: Museums, Communities, and Climate Change. New York: Routledge.

Ordway, Samuel, Jr. 1953. Resources and the American Dream. New York: Ronald Press.

Orwin, Naomi 2016. "The Anthropocene Becomes Art: Digging the Future Out of the Present," Broad Street Review: Where Art and Ideas Meet (August 22) (www.broadstreetreview.com/ wnwn/the-anthropocene-becomes-art-digging-the-future-outof-the-present).

Pleistocene Park (www.pleistocene-park.ru/).

Poultry World. 2009. "Broilers: Grand Opening of the National Poultry Museum," (May 8) (www.poultryworld.net/broilers/ markets-trade/2009/5/grand-opening-of-the-national-poultry-museum-wp00e907w/).

Popper, Deborah E. and Popper, Frank J. 2004. “The Great Plains and the Buffalo Commons," Janelle, D.G., Warf B., Hansen, K., eds. World Minds: Geographical Perspectives on 100 Problems. Dordrecht: Springer.

Purdy, Jedediah. 2016. "The New Nature," Boston Review (January 11), (http://bostonreview.net/forum/jedediah-purdy-new-nature\#.WyZq-Rk8VcQ.email).

Ripple, William J. et al. 2017. "World Scientists Warning to Humanity: A Second Notice. Bioscience (November 13), bix125 (https://doi.10.1093/biosci/bix125).

Samuels, David. 2011. "Where the Buffalo Roam," Mother Jones, (March/April).(www.motherjon es.com/environment/2011/02/buffalo-commons -americas-prarie-foundation/\#). 
Schleicher, Jerry. 2009. "A Poultry Industry History Museum Worth Crowing About," Farm Collector (October) (https://www.farmcollector.com/equipment/ poultry-industry-history-museum).

Schwägerl, C. 2014. The Anthropocene: The Human Era and How It Shapes Our Planet. Santa Fe, NM: Synergetic Press.

Steffen, Will et al. 2011. "The Anthropocene: From Global Change to Planetary Stewardship," Ambio, DOI: 10.1007/ s13280-011-0185-x.

The National Atomic Testing Museum. 2017. (www.nationalatomictestingmuseum.org).

The National Museum of Atomic Science \& History. 2017. (www. nuclearmuseum.org).

Vernadsky, Vladimir. 1945. "The Biosphere and Noosphere," Scientific American, 33 (1): 1-12.

Weber, Max. 1958. The Protestant Ethic and the Spirit of Capitalism. New York: Scribners.
White, Richard. 1996. The Organic Machine: The Remaking of the Columbia River. New York: Hill \& Wang.

Witcomb, Andrea. 2003. Re-Imagining the Museum: Beyond the Mausoleum. London: Routledge.

Zalasiewicz et al. 2017. "The Working Group on the Anthropocene: Summary of Evidence and Interim Recommendations, Anthropocene, Vol. 19 (September): 55-60.

Zimov, Sergey A. 2005. "Pleistocene Park: Return of the Mammoth's Ecosystem," Science, 308, no. 5723 (May 6), 796-798. 
